\title{
The Decline of Particularism in Japanese Politics
}

\author{
Gregory W. Noble
}

Particularistic spending has played a storied role in Japanese politics, but during the last decade of LDP rule, expenditures on roads, bridges, agricultural projects, and the like steadily lost ground to more programmatic outlays on social welfare, science and technology, and public order (but not defense or foreign aid). Prime Minister Koizumi played an important role in this shift, but the trends preceded him and continued under his much weaker successors. The end of the Cold War, increasing foreign investment, and the weakness of the domestic economy probably played mostly minor roles in the decline of particularism. The aging of Japanese society, not least in rural areas, created direct pressure for programmatic spending, while partisan upheaval, the growing share of floating voters, and reforms to the electoral and administrative systems created both an incentive and a greater capacity to redirect attention to the concerns of median voters.

KeYwords: Japan, Liberal Democratic Party, budget, particularism, infrastructure, public works, electoral reform

n 2009, the Democratic Party of Japan (DPJ) won a decisive electoral victory over the long-dominant Liberal Democratic Party (LDP). The DPJ's electoral manifesto pledged to "put an end to the vested interests of zoku giin (Diet members representing special interests) and 'Kasumigaseki' (the central bureaucracy), interests that have become entrenched over the decades of LDP rule" (Democratic Party of Japan 2009, 19) while increasing government spending on areas of interest to broad segments of the population, such as child rearing, education, health care, pensions, and welfare.

The DPJ's pledge echoed long-standing criticisms that Japan's particularistic political system stinted on policies benefiting the populace as a whole while wasting the hard-earned money of taxpayers on rural 
airports serving a mere handful of farmers, roads and bridges to nowhere, and dubious "tourist attractions" that attracted more government investment than tourists. Spending on public works and agriculture projects increased during the 1990s, despite mounting evidence that they provided ever less stimulative bang for the public buck, or yen. Particularistic policymaking sustained Japan's Liberal Democratic Party in power years after other long-lived ruling parties, such as Sweden's Social Democrats or Italy's Christian Democrats, lost predominance or even fell apart.

Political actors were not alone in focusing on particularistic spending. Scholars also assiduously documented the central role of particularism in Japanese politics, from factionalism and the infamous rule of Kakuei Tanaka's political machine in the 1970s and 1980s (Johnson 1986), to the increasing control over distributive policies exerted by powerful midlevel LDP leaders in the 1980s (Inoguchi and Iwai 1987), and the remarkably wide range of particularistic policies in Japan (Calder 1988). Analysts increasingly highlighted the strong incentives that the electoral system used in Japan before 1994, created for politicians to use particularistic politics to create a reliable personal vote (Reed 1994; Carey and Shugart 1995). More recently, Patricia Maclachlan (2004) explored the ways in which postmasters collected the vote for the LDP, Ethan Scheiner (2005) attributed the length of LDP rule to the particularly powerful role of particularism in the rural districts that provided the LDP with a virtually unassailable electoral core, and Jun Saito (2009) investigated the importance of access to infrastructural spending to legislators' decisions to cross parties. Particularistic spending became the mother's milk not only of politics, but of studies of the Japanese political system as well.

Close examination reveals, however, that particularistic spending under the last years of LDP rule was not as rigid as the DPJ's criticism suggests. After peaking in the late 1990s, public works expenditures sharply declined, as did many other forms of particularistic spending. In contrast, outlays on broader areas such as pensions and health care expanded sharply. This article documents changes in central government expenditures across a wide range of policy areas. It draws onand directs the reader to - an array of Japanese and other sources that have been underutilized in the debate about government spending in Japan. It then considers possible explanations for the shift, including the international environment, economic conditions, demographic changes, and electoral and administrative reforms, and concludes with 
a consideration of the consequences of this shift for Japan's political development and for studies of Japanese politics.

\section{Particularism in Japan}

In particularistic politics, politicians direct government spending to electoral districts or narrow economic constituencies in return for political support. Some authors use the closely related term clientelism. Scheiner (2005, 3-4), for example, writes that "clientelist parties create direct bonds with voters, usually through side payments" of pork barrel spending and other private goods. Traditionally, however, "clientelism" has tended to emphasize the relationship between individual politicians and their supporters more than the role of parties. The concept of clientelism also threatens to conflate motivations with outcomes. Some bridges are constructed not to satisfy long-term clients but to tempt marginal supporters, and not all bridges are built to satisfy political considerations; while the exact siting and construction contracts to build a specific bridge might be influenced by political calculations, some spending on bridges and other infrastructure would be required even in the absence of political factors.

In Japan, analysts describe particularism as "interest inducement" and "the politics of money and power" and often analyze policymaking by "tribes" of midlevel Diet members who compile a "telephone book" of demands each budget season (Nihon Keizai Shinbunsha 1983; Inoguchi and Iwai 1987). Japanese scholars and journalists also often include bureaucrats as a crucial element of particularistic politics, charging that ministries and agencies craft policies of which the bureaucrats themselves are prime beneficiaries. To outsiders, this may seem strange. The Japanese bureaucracy has long been hailed as a model of Weberian organization in which central ministries engage in meritocratic recruitment and determine promotion internally, with few political or patronage appointments and little reference (at least up to the very top of the bureaucratic hierarchy) to external groups (Koh 1989). In Japan, however, ministries have attracted strident criticism for having excessively close links to specific constituencies and for creating public or quasi-public agencies under their jurisdiction solely or largely to provide cushy and lucrative amakudari (descent from heaven) posts for bureaucrats after they retire from the ministry. The criticisms are not new, but they have grown in intensity as Japan's economic performance has weakened (Nakano 2009). 
Whichever term is used, operationalization of particularism can be tricky. As Scheiner's definition suggests, one approach is to contrast public and private goods. Public goods such as lighthouses, national defense, or air pollution abatement are characterized by nonexclusion and nonrivalrous consumption: even those who do not provide or pay for the goods cannot be excluded from their enjoyment, and use by one person does not reduce the benefit to others. In practice, though, rarely are goods purely public. Many "club goods" (satellite television broadcasts, for example) can be provided on an exclusive basis, while common pool resources such as ocean fisheries or underground aquifers are subject to a degree of crowding. In contrast, some partly private goods (basic research, for example) have large externalities. Moreover, many goods have both a broad and a narrow aspect: mandatory education can be a quasi-public good available to all school-age children and benefiting both them and society as a whole, while a contract to build a particular school can be a form of pork barrel spending. Ultimately, the question boils down to who the political community decides is best placed to provide the good (Noble 1998).

Rather than asking whether a good is perfectly "public" in the technical sense, it may be more useful to focus on whether public funding or provision goes to (or creates externalities affecting) large classes of people who do not overwhelmingly support a single politician or political party. National health care, for example, covers the entire population, while public pensions and compulsory education subsume whole age cohorts. Since parties and governments regularly promise to improve the supply or quality of broadly distributed goods such as education and health care, I refer to these as "programmatic" goods. Thus, I leave aside the issue of whether particular expenditures are inadequate or excessive, or whether alternative forms of provision would be possible or desirable. The focus here is on the changing size and composition of publicly funded activities rather than on their desirability. Since we often lack precise metrics of just how particularistic or programmatic an item is, I provide evidence on a wide range of programs.

Particularism can be immensely attractive to politicians because benefits are concentrated on the interest group or geographic constituency receiving the good, while the costs are diffused across all taxpayers (Wilson 1989). Several factors made particularism especially attractive in Japan. The single, nontransferable vote (SNTV) system used in Japan's House of Representatives from 1925 to 1994, in which most electoral constituencies contained two to five seats, created competition among candidates running against fellow partisans in the same districts. 
Intramural conflict undermined the effectiveness of party labels, contributed to the emergence of factions, and weakened the control of the central party over individual Diet members, faction leaders, and even members of the cabinet. Unable to distinguish themselves effectively on the basis of party label or ideology, backbench politicians lobbied hard for opportunities to claim credit for bringing home the tonkatsu (pork). Particularistic programs and agencies for farmers, small business owners, and construction companies proliferated (Hirose 1989). A major study in the late 1980s found that Japan was the only major country to provide every possible type of public policy to support small businesses (Calder 1988).

Scheiner (2005) acknowledges the importance of the electoral system but highlights another factor: Japan's centralized system of public finance, which greatly weakened the ability of nonruling parties to compete at the local level, since they had limited access to resources not controlled by the ruling party. He also notes the path dependence of clientelism (prewar politicians shoveled money to landlords, who ensured that their tenants voted for the correct party) and the self-reinforcing character of predominant party rule under clientelist politics, since outparties have a hard time recruiting good candidates, particularly at the local level.

The organization of Japan's private sector reinforced particularistic policymaking. The public sector, large private employers, and even many small and medium-sized firms provided long-term employment to core employees. Layoffs were not impossible, and coerced early retirement was fairly common, but court rulings supported social expectations that firms were not to release employees unless they faced dire circumstances. Temporary and irregular workers, most of them women, but also many young males, bore most of the burden of adjustment. Largely protected from fear of unemployment, male breadwinners and their dependent wives were disinclined to become deeply involved in partisan disputes over ideology. In the late 1990s, Hideo Ötake (1999) lamented that the Japanese employment system undermined socioeconomic cleavages around which programmatic political parties could emerge.

To be sure, in some ways Japan was not unique, and many public policies were programmatic in character. International precedents and socioeconomic changes such as urbanization pushed up programmatic spending in the 1960s and 1970s. National systems for pensions and health care, although complex, fractured, and based on employment status, appeared in the early 1960s, while 1973 marked the "first year 
of welfare," including free medical care for the elderly (later somewhat weakened). In the 1970s, regulations led to a sharp increase in spending on pollution abatement.

The 1980s and early 1990s, however, witnessed a resurgence of particularism, including increased spending on the rapidly shrinking agricultural sector and an expansion of public works. Even when the collapse of the bubble economy highlighted the weaknesses of the old particularistic political system, countervailing forces appeared weak. After 2001, Prime Minister Junichiro Koizumi imposed some cuts, but many observers dismissed his efforts as fake or at best sui generis (Eda 2004; Financial Times, October 17, 2007). Whatever Koizumi accomplished, it seemed, was possible only under unusual circumstances, and he was followed by short-lived, politically weak successors.

\section{Evidence of Past Particularism}

Even if the picture of Japan as nothing but a "construction state" presided over by Kakuei Tanaka, the LDP's "computerized bulldozer," and his successors is exaggerated, systematic evidence of past particularistic tendencies is plentiful, and in many cases the shift toward more programmatic spending that occurred in the 1960s and 1970s partially reversed course in the 1980s and 1990s (Curtis 1988, 236). Fixed capital investment by the government generally ran at 5-6 percent of GDP through the 1970s, considerably more than the level in the next highest major industrial country (France), and about twice that in the UK, the United States, and Germany. Public investment dipped in the early 1980s and stabilized in the latter part of the decade, but the bursting of the financial bubble in the early 1990s pushed the Japanese level back over 6 percent, more than double the rate in the United States and triple that in the UK and Germany. ${ }^{1}$

Other programs aimed at small minorities of the population showed similar patterns. The budget of the Ministry of Agriculture, Forestry and Fisheries (MAFF), for example, remained imposing despite the small size and steady decline of the farming and fishing communities. The MAFF budget accounted for 4.6 percent of all General Account (GA) spending in 1988; the share of general or policy expenditures (ippan saishutsu), calculated by subtracting debt payments and local allocation taxes from the GA budget, amounted to 8.6 percent. By 1998, MAFF's share of the GA budget had slipped a fraction to 4.5 percent, but its share of policy expenditures had actually increased a bit to 
8.8 percent. $^{2} \mathrm{~A}$ widely cited example of the waste and rigidity was the number of agricultural statisticians, who had totaled around 12,000 in the early 1960s. As late as 2000, Japan still had 5,979 agricultural statisticians, despite extraordinary improvements in information technology and the stagnation of agricultural output after the early 1970s (Ihori 2008, 80).

Another potent symbol of Japan's excessive devotion to particularistic spending is the Fiscal Investment and Loan Program (FILP). Sometimes referred to as Japan's "second budget," FILP is funded by postal savings and public pension monies. While FILP is complex and includes a range of accounts of quite different types, parts of it are highly particularistic. From the 1950s to the 1970s, the program expanded rapidly as economic growth swelled the coffers of the postal savings system, and FILP came to equal about one-third the size of the GA budget. Financial liberalization then caused a big drop as attractive new investment opportunities lured deposits away from the postal system. FILP investments also grew more particularistic and less dedicated to furthering economic development: FILP devoted fewer funds to industrial development, telecommunications, science, and education and more to the promotion of small and medium-sized enterprises, urban development, and road building.

The bursting of the financial bubble, moreover, sent deposits surging back into the post office, as interest rates on alternative investments collapsed and the risks of newly liberalized markets became apparent. The FILP peaked at over 40 percent of the size of the GA budget in 2000. The biggest increase came in housing. The Japan Housing and Urban Development Corporation took an increasing share of the home mortgage market, depriving banks of a large and relatively stable business, thus contributing to the woes of the Japanese banking system after the financial bubble burst. But it was not particularly particularistic. Homeowners were a large and diverse group, probably only mildly more inclined than the population at large to vote for the LDP. Other major growth areas, however, were more particularistic in character, notably a variety of programs to support small businesses, many of which provided a crucial source of money and votes for the ruling party (Noble 2005).

Over the course of the 1990s, the Japanese government, once the most abstemious in the Organization for Economic Cooperation and Development (OECD) - excepting only Korea, a recent and still developing member-rapidly expanded its share of GDP. General outlays by the Japanese government accounted for only 32.7 percent of the economy in 1992 but hit 39.0 percent in 2000. The situation in Japan 
contrasted markedly with the OECD average, which dropped 3.6 percentage points over the same period to 38.7 percent. $^{3}$

Despite this major expansion of the governmental sector, provision of programmatic goods in Japan remained lower than in most other advanced democracies. In 2001, Japan ranked nineteenth out of twentythree OECD countries in public social expenditures. Pensions and health care expenditures only slightly trailed OECD averages, but all other forms of social spending were extremely meager. Unemployment insurance was highly restricted. Spending on public assistance, already very low in comparative perspective, fell in the early 1990s even as the economy weakened and barely made up for the decline in the late 1990s (Ikeda 2008, 107). Private social expenditures, in contrast, ranked seventh, very similar to the UK, suggesting that demand for social services in Japan was by no means low. ${ }^{4}$

Spending on education and research also trailed OECD averages. Compulsory education dated back to the Meiji period, and by the 1980s the vast majority of students graduated from senior high school, but the government restrained spending by keeping class sizes very large. Similarly, the government kept a tight rein on spending for public tertiary education. Private colleges and universities expanded rapidly in the postwar period, and the government reluctantly responded by increasing subsidies; but by the late 1970s it began retrenching. Public spending on research and development was also noticeably lower than in most other OECD countries. As a share of GDP, government-funded research and development (R\&D) actually declined during the bubble economy (MEXT 2008, 9). When it came to public safety, the government relied heavily on community pressures. A modest number of police, prosecutors, judges, and prison personnel sufficed to keep crime rates at low levels.

Spending on defense also remained restrained. After the mid1970s, the government restricted defense spending to about 1 percent of GDP (slightly higher if military pensions are included, as in NATO countries). Under Prime Minister Nakasone in the mid-1980s, defense spending marginally exceeded the 1 percent level for a time, and strong GDP growth during the bubble period sustained higher expenditures. After 1990, however, defense spending slowed in tandem with economic growth. The public generally supported the status quo but did not rank defense spending as a high priority. Most defense spending was not particularistic, though high prices for military equipment and occasionally shady procurement practices ensured special benefits for intermediaries and for producers of munitions and dual-use equipment. 
Expenditures on foreign aid or "economic cooperation," in contrast, nearly doubled from 1985 to 1995 , when they topped 1 trillion yen. Aid constituted about 2.3 percent of all policy expenditures, or roughly 0.35 percent of GDP, and Japan became known as an aid power. For the next five years, economic cooperation expenditures stayed at about the same level. ${ }^{5}$ Traditionally, critics assailed foreign economic assistance as little more than a subsidy to Japan's export industries, but a series of reforms "untied" most Japanese aid packages.

Particularism, then, was indeed a persistent theme under LDP rule. Japan was not unique in engaging in pork barrel or narrowly targeted spending, of course, and the role of particularism varied somewhat over time. From the early 1960s to the late 1970s, programmatic spending, especially on social welfare, expanded rapidly. From the early 1980s, recurrent movements for "administrative reform" tried to restrain all types of spending. But in the 1990s, public works and other forms of particularistic spending actually increased in response to the bursting of the financial bubble.

\section{Declines in Particularistic Spending}

From the late 1990s, however, particularism markedly declined. First, it is important to note that despite weak and uncertain economic growth and the steady aging of Japanese society, total expenditures were surprisingly restrained after the turn of the century. From 2000 to 2007, while government spending in most OECD countries increased slightly, total general government outlays in Japan declined to 36.0 percent of GDP from 39.0 percent, putting Japan back well under the OECD average. ${ }^{6}$ Few observers noticed that the real cause of Japan's deficits was not increasing expenditures but the collapse of revenues, which sank to levels not seen in twenty years. When tax revenues recovered slightly after 2003, Koizumi and his successors did not spend them but applied them to reducing the deficit. In Japan, alone among the G5 countries, outstanding gross public debt as a share of GDP actually declined from 2005 to 2008 (Ikeda 2008, 348-349). In 1998, the general financial balance of the Japanese government (central and local) equaled -11.2 percent, by far the worst in the OECD; by 2008, Japan's budget deficit of -2.7 percent was better than the OECD average and far better than that of the United States or the UK. ${ }^{7}$

The budgets compiled in 2008 and 2009 in the face of global economic crisis and a looming general election were especially telling. The 
2008 budget was only 0.2 percent larger than the 2007 budget. After the global financial system seized up in the fall of 2008 , the government compiled two supplementary budgets, totaling 6.6 trillion yen, or about 1.3 percent of GDP, much lower than in the United States or China. The focus of Japan's package was not on public works but on Prime Minister Taro Aso's idea of handing 12,000 yen to each adult resident of Japan, the antithesis of a particularistic strategy. The public roundly rejected the idea, but not in favor of public construction; instead, public opinion called for expenditures on programmatic goods such as unemployment measures, medical care, and education (Asahi Shinbun, March 4, 2009). The supplementary budgets did include considerable outlays on small and medium-sized enterprises, but little for public works or agriculture. ${ }^{8}$ For 2009 , the government increased spending 6.6 percent but cut public works a further 5.2 percent. ${ }^{9}$ Facing doubledigit declines in real GDP in the final quarter of 2008 and the first quarter of 2009, and a deadline for a lower house election that polls showed the LDP would lose, the government added a large supplementary budget in the spring of 2009 totaling 15 trillion yen, about 3 percent of GDP, with a focus on financial stabilization, energy technology, and support for local governments rather than public works. ${ }^{10}$

The decline of public works spending continued a well-established trend. In 2008, spending on public works fell to 2.9 percent of GDP, less than half the peak of the late 1990s. ${ }^{11}$ During the period 2001-2007, while private construction contracts increased 21 percent, public sector construction contracts declined by 44 percent; contracts for agriculture and for forest and river management shrank by almost 52 percent. ${ }^{12}$ The government, led by the Ministry of Finance, also made repeated efforts to slice away the fat from public works contracts, thus decreasing their "private" character. While collusive bidding and featherbedding did not disappear, unit costs declined somewhat (Kamemoto 2005). ${ }^{13}$

Agriculture displayed a similar pattern. By 2008, the Agriculture Ministry's share of the budget declined to 2.8 percent (5.0 percent of the policy budget). The 2009 budget imposed a further 2.9 percent cut, largely in the form of reductions for agriculture-related public works. Funding for agricultural land improvement districts, cited by Scheiner (2005, 70-73) and others as a particularly juicy bit of particularistic spending because the benefits could be targeted precisely to specific constituents, declined 21 percent between 2001 and 2007. ${ }^{14}$ In 2008, the government abolished the special account for land improvement and folded its activities into the GA budget. As for agricultural statisticians, the Koizumi government specifically targeted them in its honeb- 
uto (big-boned) economic program for 2006. Only 3,493 were left in 2007, a drop of 40 percent compared with $2000 .{ }^{15}$

Reductions in the Fiscal Investment and Loan Program were equally dramatic. Reform began in the latter half of the 1990s under Prime Minister Ryutaro Hashimoto. It continued steadily and rapidly under Prime Minister Koizumi, including measures to allow more freedom to invest post office savings outside of FILP, and, in 2005, passage of legislation to privatize the post office. By 2008, the flow of FILP funds had declined by two-thirds compared to its peak in the 1990s, while the stock of funds was down by one-half. Around one-fourth of the initial flow was replaced by "FILP agency bonds" issued by the various agencies funded by FILP. Some critics charged that this amounted to pouring a bit of the old wine into new bottles, but the new bonds allowed investors to distinguish the relative creditworthiness of different FILP agencies and gave the agencies an incentive to improve their operations and financial soundness rather than just waiting for the post office funds to come rolling in (Noble 2005; Ikeda 2008, 265-280).

The popular argument that Japan's bureaucracy was uniquely particularistic, and that the solution to Japan's fiscal problems was to reduce the number and wages of Japanese bureaucrats (Yomiuri Shinbun poll, December 10, 1996), receives little support from comparative evidence. The Japanese bureaucracy was long the most lightly staffed in the advanced democracies. From 1967 to 2000, the number of bureaucrats in Japan remained virtually constant, even as the population increased by more than one-third; the consolidation of ministries in 2001 further compressed the number of employees. In 2007, Japan had 32.5 public servants per 1,000 residents, compared to 78.0 in the United States, 79.2 in the UK, and 87.1 in France. Even Germany (54.9) had nearly twice as many bureaucrats as Japan (Zaidan Hōjin Gyōsei Kanri Sentaa 2008, 17-18). ${ }^{16}$ Wage levels were pegged to those of the private sector, though less flexible: local civil servants in remote areas received generous salaries relatively to the cost of living, while public sector employees in large cities were, if anything, underpaid (Ihori 2008, 77-117). Japanese public servants enjoyed strong job tenure, but all but a few passed up the chance to advance to highly lucrative executive positions in private firms.

Pressures on bureaucratic spending tightened over time. The government took steps to restrain salaries, including changing the sample of private firms with which public salaries were compared from firms with 100 or more employees to those of fifty or more. General administrative expenses in local government, the site of the large majority of 
public expenditures, peaked in 1999 at 19.7 trillion yen, then declined to 18.2 trillion yen in $2005 .{ }^{17}$

The contention that Japanese bureaucrats were uniquely, or at least unusually, "private-regarding," and that public policy was systematically distorted in a particularistic direction to provide former bureaucrats with lucrative second careers, is harder to evaluate, not least because charges that bureaucrats make work for themselves are not limited to Japan. Evidence, however, suggests some movement away from the coziness of the past. The Koizumi government significantly cut the retirement benefits from amakudari posts, and reduced the number of special corporations accepting amakudari directors. Particularly striking was Koizumi's insistence on merging, privatizing, and downsizing the group of government-affiliated financial organizations that had long served as especially comfortable postretirement destinations for elite bureaucrats from the Ministry of Finance and other leading agencies. Koizumi also established the principle that former bureaucrats should not serve as the heads of public policy companies (Noble 2005, 120-121).

Koizumi's successor, Shinzo Abe, promoted the idea of moving control over amakudari appointments away from individual ministries and into a centralized "job bank." Disagreement between reformers and old guard members of the LDP threatened to undermine civil service reform, but in the end the DPJ, which had won a majority in the House of Councillors, succeeded in backing the LDP reformers against the old guard, who lost on five of seven disputed elements. The resulting civil service reform law established control over amakudari in the Cabinet Office rather than in an independent agency, required bureaucrats to record and make public all contacts with politicians, and proposed extending retirement ages for elite bureaucrats so that they would not be forced to seek amakudari posts. The leader and the majority of the staff in the new "civil service reform headquarters" created in the cabinet to implement the new law hailed from the peak business association Keidanren and the private sector (Asahi Shinbun, February 21, May 28, June 12 , July 4 , 2008). ${ }^{18}$

Prime Minister Aso originally seemed reluctant to push amakudari reform, but under pressure from the DPJ he told the Diet that even in special circumstances he would not approve applications to allow former bureaucrats to "migrate" to secondary or tertiary amakudari appointments. A few days later, overcoming opposition from the National Personnel Agency, which feared loss of jurisdiction, and members of the LDP sympathetic to the ministries, he announced that a new per- 
sonnel system would be established to "eradicate" amakudari (or at least its mediation by the ministries) by the end of 2011. Planned measures included centralized control of bureaucratic careers and creation of specialized posts that would end the de facto "up or out" rule and allow civil servants to continue working in the government until retirement (Yomiuri Shinbun, January 29, February 3, 2009; Shūkan Tōyō Keizai, February 17, 2009).

In practice, exerting effective limits over amakudari was difficult. For example, newly installed private leaders lacked adequate staff to overcome the incestuous relations maintained by lower-level amakudari members who maintained close contact with their former ministries (Wedge, December 2007, 10-12), nor did the creation of Abe's "job bank" have much impact, at least initially (Asahi Shinbun, October 8, 2009). No final resolution to the problem of amakudari appointments is possible as long as masses of elite bureaucrats are forced to retire at relatively young ages and private companies remain reluctant to hire midcareer employees. Nonetheless, the last years of LDP rule witnessed considerable efforts - energetic under Koizumi, more reluctant under his successors - to reduce the incentives for and impact of amakudari.

\section{Increases in Programmatic Spending}

While particularism in the form of both targeted spending and cushy jobs for former bureaucrats waned from the late 1990s, expenditures on programmatic goods increased virtually across the board. In 1985, social spending accounted for 29.4 percent of policy expenditures. As late as 2000 , social spending still accounted for little more than a third of the policy budget ( 35 percent), but by 2008 it reached nearly half ( 48 percent). ${ }^{19}$ The government did not just mechanically accept the fiscal consequences of aging. In some cases, it strove to constrain spending: the LDP under Koizumi pushed through a major revision to public pensions in 2004, hiking premiums and cutting benefits (Yoshida, Guo, and Cheng 2006). In other cases, however, it took affirmative-and expensive-steps to expand social coverage. In 2000, the government instituted a system of insurance for the long-term care of the elderly, which quickly became a major budget item. In 2009, the government increased social spending a whopping 14 percent, largely to cover an increase in the subsidy rate on basic national pensions to 50 percent. $^{20}$

At first glance, education does not seem to have fared as well. Education spending accounted for 13.6 percent of the policy budget in 
2000 but only 10.3 percent in 2008 . This drop, however, reflected mainly the steep decline in children of school age and the "trinity" reforms to local finance, under which the central government, starting in 2004 , cut its share of payments for compulsory education to one-third from one-half, in return for turning some tax revenues over to localities. As a result, the teacher-student ratio for elementary and secondary schools dropped precipitously, becoming comparable to schools in other advanced democracies (while average class size also declined, it remained higher in Japan than in most other countries, reflecting the greater time allotted to Japanese teachers for class preparation) (OECD 2000, 15; OECD 2008, 219, 304, 436-437, 440).

Spending on tertiary education grew to slightly higher than average among OECD countries. The proportion of students proceeding to tertiary education increased markedly, and many students who formerly would have attended junior colleges matriculated at four-year universities. Corporatization of the national universities was followed by steady cuts in government support, only partially offset by increases in funding of competitive grants. Overall, however, spending per student increased significantly (OECD 2009, 23, 202, 207).

In the case of senior high schools, it could be argued that the improved teacher-student ratio simply reflected the difficulty of firing teachers, since the decline in pupils was so rapid that it outran normal attrition in the teaching force. The difficulty of firing teachers does not explain outcomes at other levels, however. University enrollments actually increased until 2006 and faculty numbers also steadily increased. For elementary and junior high school, declines in the number of students continued, albeit at a slowing pace, but the number of teachers hit bottom in 2000 and 2006, respectively, and began to increase again. ${ }^{21}$ Rather than cutting every possible teacher, the government began to hire new ones. The 2009 budget, for example, provided funds for the Education Ministry to hire 1,000 new teachers and to bring back 14,000 retired teachers (and other people with relevant experience) on a parttime, contract basis. ${ }^{22}$

Spending on research and development also increased. From 1996 to 2008, the government's expenditures on science and technology increased over 75 percent, compared to an increase of less than 10 percent in all general (policy) expenditures. ${ }^{23}$ The ratio of governmentfunded R\&D to GDP, much lower than in other advanced countries through the bubble period, moved in the next decade and a half to equal the level of Europe. ${ }^{24}$ As with education, one could argue that the increases were inadequate; as in most countries, government outlays fell 
far behind the surge in R\&D spending by private firms. But there is no question that spending on this important programmatic good increased substantially.

Similarly, despite Japan's stable society and fiscal plight, spending on public order increased strongly. Budget authorizations for police, judges, prosecutors, and prison personnel all increased much more rapidly than in the preceding decades. From 2000 to 2009, the number of prefectural police officers increased 9.9 percent, slightly more than the total increase over the preceding two decades. Especially striking was the one-third increase in national police officers, also slightly more than in the preceding two decades (National Police Agency, various years). Expansion in budget authorizations for judges and public prosecutors was even more dramatic. From 1980 to 2000, the number of judges increased only 2.8 percent; from 2000 to 2008 , the number jumped to 3,491 , an increase of 23.7 percent. ${ }^{25}$ Similarly, the number of prosecutors increased just 8.5 percent between 1980 and 2000, with most of that increase coming at the end of the 1990s. Indeed, between 1981 and 1995 , the budgetary allocation remained fixed at precisely 2,070 prosecutors. Increases began in 1996, and between 2000 and 2008 the government hired 325 more prosecutors, a jump of 15 percent (Ministry of Justice 2008, 393-396). Prison guards barely budged from 1980 to 2000 , increasing less than 1 percent, but then increased 8.8 percent from 2000 to 2008 , supplemented by a major expansion of outsourcing to private prison contractors (Ministry of Justice, various years). ${ }^{26}$

Even if these increases in support for public order simply represented responses to changed environmental conditions, they would have constituted important political developments. But the correspondence was weak. Official surveys of crime victims revealed a major $d e-$ crease in the incidence of crime from 2000 to 2008, further solidifying Japan's position as the safest of the major democracies (National Police Agency 2008). To be sure, from the late 1990s, changes in procedures, partly in response to a series of scandals, led the police to report far more incidents as criminal cases, resulting in widespread popular fear that Japan suffered from a "crime wave," though people reported far fewer fears about the communities in which they actually lived (Hamai and Ellis 2007). Yet even this supposed wave crested in 2002, falling by more than one-third over the next six years. Surveys revealed an easing of public concern about crime, but spending on public order continued its rapid advance (National Police Agency 2009, 52). ${ }^{27}$

If spending on domestic programmatic goods such as social welfare, research, and public order strongly increased from the late 1990s, 
expenditures on externally oriented programmatic goods decreased. Spending on "economic cooperation" declined sharply, if erratically. Economic cooperation accounted for 2 percent of the policy budget in 2000 but only 1.4 percent in 2008 , less than the 1.8 percent level of 1985, when no one talked of Japan as an aid superpower.

After increasing at 9 percent a year from the mid-1970s to the mid1980s, and growing at a still healthy 4.2 percent a year through the early 1990s, defense spending hit a plateau in the mid-1990s. Under Koizumi and his LDP successors, defense spending declined a tiny fraction every year from 2002 through 2009, leaving the budget almost exactly as large in nominal yen as it had been in $1995 .^{28}$ Despite rationalization campaigns and increased use of outsourcing, substantial increase in personnel costs over the course of a decade and a half forced the defense agency (from 2007, Defense Ministry) to cut spending on major weapons platforms, which declined 28 percent from 1990 to 2000, then another 12 percent from 2000 to 2008 (Ikeda 2008, 176). Stung by repeated scandals, including the arrest for bribery of a former vice-minister, the Defense Ministry pledged to undertake reforms to reduce the murky and particularistic aspects of Japanese procurement. A stark contrast emerged between the stagnation of Japan's defense budget and robust increases in defense spending by crucial neighbors such as China and South Korea, and the United States.

Table 1 provides a summary of the major trends in particularistic and programmatic expenditure described in this section, focusing on developments in the largest categories and those most commonly associated with Japanese spending in each category. The trends are unmistakable: domestically oriented programmatic spending increased, while particularistic spending and externally oriented programmatic spending decreased.

\section{Why the Shift from Particularism?}

Explaining the shift away from particularistic spending and toward expenditures on domestically oriented programmatic goods over the final decade of LDP dominance will be an important research topic in coming years. While the dynamics and timing inevitably varied somewhat across categories of government activity, the uniformity and magnitude of the shift suggest that powerful systemic forces were at work. At the same time, the likely influences are numerous and interconnected. This section briefly canvases some of the likely causes. 
Table 1 The Shift Away from Particularistic Spending in Japan

\begin{tabular}{|c|c|c|}
\hline Policy Type & Policy Area & Changes from the Late $1990 \mathrm{~s}$ \\
\hline \multirow[t]{6}{*}{ Particularistic } & Public works & $\begin{array}{l}40 \% \text { cut in expenditures; less than half as } \\
\text { large a share of GDP }\end{array}$ \\
\hline & Agriculture & Budget share down more than $40 \%$ \\
\hline & $\begin{array}{l}\text { Fiscal Investment and } \\
\text { Loan Program (FILP) }\end{array}$ & $\begin{array}{l}\text { Flow: down by } 2 / 3 \text { (about } 1 / 4 \text { replaced by } \\
\text { agency bonds) }\end{array}$ \\
\hline & & Stock: down by more than half \\
\hline & Civil servants/amakudari & $\begin{array}{l}\text { Slight decrease from low levels }(32.5 / 1,000 \\
\text { residents vs. } 78 / 1,000 \text { in US) }\end{array}$ \\
\hline & & Moves to restrict amakudari \\
\hline \multirow[t]{8}{*}{ Programmatic } & Social welfare & 2000: $35 \%$ of general (policy) budget \\
\hline & & 2008: $48 \%$ of general (policy) budget \\
\hline & Education & $\begin{array}{l}\text { Budget share down, but much less than } \\
\text { decline in school-age population }\end{array}$ \\
\hline & & $\begin{array}{l}\text { Sharp improvement in teacher-student } \\
\text { ratios in primary and secondary schools }\end{array}$ \\
\hline & Research and development & Spending steadily up since early 1990 s \\
\hline & $\begin{array}{l}\text { Public safety (police, } \\
\text { prosecutors, prison } \\
\text { guards, judges) }\end{array}$ & $\begin{array}{l}\text { Spending steadily up, and at much faster } \\
\text { pace than in } 1980 \text { s and early } 1990 \mathrm{~s}\end{array}$ \\
\hline & ODA & $\begin{array}{l}\text { Sharply off from peak of late 1990s (but } \\
\text { wide fluctuations) }\end{array}$ \\
\hline & Defense & $\begin{array}{l}\text { Down slightly in absolute terms (steady, } \\
\text { slight decline) }\end{array}$ \\
\hline
\end{tabular}

International Environment

The collapse of the Berlin Wall in 1989 and the dissolution of the Soviet Union in late 1991 essentially ended the Cold War, making it far easier for an opposition party to come to power in Japan without risking a rupture in the security alliance with the United States. As head of an odd-fellows coalition cabinet with the LDP in the mid-1990s, JSP leader Tomiichi Murayama formally accepted the legitimacy of the Self-Defense Forces and the United States-Japan security treaty. This fatally weakened the JSP's left wing, making it possible for a more moderate center-left party to emerge and present a genuine challenge to the LDP and its particularistic ways (even so, the United States expressed some discomfort about the security policies of the new DPJ government).

After the late 1960s, Japan became a large net creditor, so it did not face international financial crises or runs on the yen. Financial independence deprived Japan of externally imposed discipline and abetted a slow, incremental approach to policymaking. To be sure, Japan was not entirely unaffected by the global financial system. Concerns about 
the weakness of Japanese financial institutions led foreign financial firms to impose a "Japan premium" on loans to Japanese banks in 1995-1997 and 2001, creating much anger and consternation in Tokyo. The Japan premium did not raise the low and declining interest rates on Japanese government bonds, but it forcefully reminded policymakers that reforms could not be postponed forever.

Inbound direct foreign investment remained remarkably limited, so limited that Prime Minister Koizumi made attracting more foreign investment - and attending to the concerns of foreign investors-a major government objective, a policy that met with some limited success. On balance, though, direct foreign investors probably played at most a minor role in the move away from particularism.

Even though Japan was still a large net creditor in international markets, indirect foreign investment in Japanese securities told a different story. In 2007, foreigners owned over 27 percent of the stocks listed on Japan's major exchanges, up from less than 5 percent in 1990. They participated in 44 percent of the trades on the Tokyo, Osaka, and Nagoya stock markets (Tokyo Stock Exchange Group 2008, 5; 2009, 4, 61). The large and growing foreign presence inspired both a nativist counterreaction, especially when foreigners tried to acquire Japanese firms, and a heightened sensitivity to how external actors viewed Japanese economic policy. Several Japanese executives in firms with high levels of foreign ownership played prominent roles in the neoliberal movement (Noble 2007, 217-219). While foreign investors generally opposed particularistic policies, they worried at least as much about increased expenditures on social welfare. The preferences and influence of foreign portfolio investors are worthy of further investigation (Tiberghien 2007), but their effect on expenditure patterns was probably limited.

A key question was when Japan would become a net debtor. During the rapid growth period, Japan was famous for high rates of savings, but in the 1990s the combination of an aging population and low and sometimes negative growth in wages and interest income depressed household savings. The disposable income of Japanese households steadily declined from 310 trillion yen in 1997 to 300 trillion yen in 2000 and 293 trillion yen in 2007. In those years, household savings rates slid from 11.4 percent to 7.9 percent to 2.2 percent (Nakata 2009). ${ }^{29}$ A shift into negative territory loomed, though the exact timing of the transition was uncertain. When households lack sufficient savings to absorb government bonds, the government will have to look to overseas buyers. Over the last decade or so of LDP rule, international constraints still did not bind, but the prospect drew closer and no doubt exerted some influence on policymakers. 


\section{The Domestic Economy}

The popping of Japan's financial bubble discredited the old system of political economy. At first, occasional erratic upturns in economic performance obscured the magnitude of the collapse in asset prices, but after the bankruptcy of Hokkaido Takushoku Bank, Sanyo Securities, and other financial firms in late 1997, the damage was undeniable. Banks struggled with a mass of nonperforming loans, and Japan gradually sank into a frightening morass of deflation.

From 1991 to 2008, real economic growth averaged just 1.2 percent per year, ${ }^{30}$ and in 2008 , the government brought in only 46.4 trillion yen in tax revenue, less than it had received in $1987 .{ }^{31}$ Gross outstanding public debt hit 171 percent in 2008, by far the worst in the OECD; net debt was not quite so terrible at 87 percent but still much higher than in all major countries save (barely) Italy. ${ }^{32}$ Thanks to record-low interest rates, payments on outstanding public debt continuously declined from 1986 relative to GDP and from 1999 in absolute terms, but in 2006 they started an inexorable march upward, effectively ending Japan's soft budget constraint. ${ }^{33}$ The Ministry of Finance continually reminded both politicians and the public that if interest rates exceeded economic growth rates, the burden of debt payments would become crushing (Ikeda 2008, 50-52). By itself, fiscal pressure did not necessarily lead to a shift from particularistic to programmatic spending, since the latter typically is expensive, but it did ensure that attention would be paid to the long-term consequences of budgetary decisions.

Changes in corporate behavior also created increasing doubts about the viability of Japan's particularistic and work-linked approach to social welfare (Estévez-Abe 2008). After the oil shocks, major Japanese firms steadily reduced investments and financial leverage. With the bursting of the bubble and the descent into deflation, Japanese companies decreased cross-holding of shares with other firms, engaged in more mergers and acquisitions, replaced permanent employees with an ever increasing proportion of temporary and part-time workers, and cut back or eliminated company housing and other forms of corporate welfare (Schaede 2008). These changes, while important, were moderate and gradual, making it difficult to assess how forcefully they affected voters and policymakers.

\section{Demographic Change}

The most direct force for the shift to programmatic spending was the rapid aging of Japanese society (Campbell 1992). In 1960, barely 5 per- 
cent of Japanese were over sixty-five. By 2006, the elderly accounted for 20.8 percent of the population, highest among the advanced industrial countries (OECD 2008, 6-7), pushing up expenditures for pensions and health care. Japan's working-age population peaked and began to decline. The shrinking workforce, in turn, contributed to Japan's slow rate of economic growth and restricted tax revenues (Ikeda 2008, 91).

Some of the most redoubtable LDP strongholds aged especially rapidly, including Yamaguchi Prefecture (25.0 percent over sixty-five in 2005), Kagoshima (24.8 percent), Wakayama (23.1 percent), and Fukui (22.6 percent). ${ }^{34}$ Farm households, traditionally among the most loyal LDP supporters, were particularly hard-hit. In 1985, 26.6 percent of farmers were over sixty-five years old. By 1995, the ratio rose to 43.2 percent, and in 2005 it hit a remarkable 58.2 percent. ${ }^{35}$ Half- and part-time farmers, who constituted the overwhelming majority of the farm population, earned the bulk of their income from nonfarm jobs. Retirement and gift income greatly exceeded earnings from agriculture. In the first years of the new century, pension income increased slightly, while agricultural income generally decreased (Shōgenji 2008, 6). The emergence of aging and declining rural areas cut both ways, creating demands for particularistic spending on public works and agricultural subsidies to rescue declining areas but also heightening concern about social welfare. For most rural residents, protecting pensions and attracting doctors and ambulances became more pressing than maintaining public subsidies to agriculture.

Other demographic shifts also contributed to the decline of particularism. In the 1980s, urban areas lost residents, but from the early 1990s, cities and suburbs gained population at the expense of rural areas. Educational levels increased, making jobs in agriculture and public works less attractive to young people. The proportion of women attending four-year universities expanded particularly rapidly, contributing to lower fertility rates and increasing concerns about child care, education, and social welfare.

\section{Shifts in Partisan Affiliation and Public Opinion}

Even before the bursting of the financial bubble, political trends began to turn against the ruling party. The LDP lost its majority in the Upper House in 1989 and briefly lost control of the Lower House in 1993-1994. Even after regaining control of the cabinet, the LDP was forced to enter into formal or informal coalitional arrangements with 
other parties. Weakening of LDP rule and reliance on coalitions directly opened the way to policy reform in a number of areas, such as introducing new laws on information openness and administrative procedures, and shifted the balance of power within the LDP away from the staunchest advocates of the traditional particularistic approach toward a more centralized approach to policy (Hiwatari and Miura 2002; Institute of Social Science 2006).

The increasing vulnerability of the LDP to shifts in voter sentiment reflected in part a weakening of the partisan orientation of the citizenry. From the 1960s to the late 1980s, Japan followed a path similar to that of the United States, as independent or floating voters (mutō hasō or seitō shiji nashi sō) increased from about 10 percent of all voters to around one-third. But in the early 1990s, while the US level remained roughly constant, the share of unaffiliated voters in Japan surged. By January 1995, independents exceeded 50 percent of the electorate. Young people and housewives were particularly numerous (Tanaka and Martin 2003). Partisan dealignment among voters preceded and contributed to defections of lawmakers from the LDP and the formation of new political parties, which in turn facilitated electoral reform. As in the United States, most self-proclaimed independent voters were not apolitical-indeed, Ikuo Kabashima (2004) argues that some floating voters were LDP-leaning "buffer players"- but they were far less firmly connected to traditional LDP support networks, less reliably motivated by promises of particularistic goodies, and deeply distrustful of politicians, bureaucrats, and government programs (Yomiuri Shinbun, December 28, 1999; Taniguchi, Sugawara, and Kabashima 2005). The rise of more diverse and lively news media, starting with commercial terrestrial broadcasters and cable TV and later extending to the Internet, provided opportunities for voters to obtain information and opinions about larger issues transcending the particularistic social networks undergirding LDP rule and contributed to the rise of floating voters (Krauss 2000).

The more volatile electorate became even less oriented toward particularism over the 1990s and early 2000s. In the mid-to-late 1990s, voters had a mixed-to-positive view of the role of public investment (Yomiuri Shinbun, November 30, 1997, May 28, 1999), but even then they were much more willing to cut public works than health and welfare benefits (Yomiuri Shinbun, December 10, 1996) and showed far greater concern for social welfare than for agriculture, community development, or small-business promotion. ${ }^{36}$ By 2008, the public opposed using public works to ameliorate regional disparities (Mainichi Shinbun, February 4, 
2008), overwhelmingly opposed building all the roads listed in the construction ministry's long-term transportation plan, and supported turning over the revenue from the dedicated gas tax to the general budget rather than reserving it for road construction and maintenance (Asahi Shinbun, February 5, March 4, 2008). When a 2008 survey asked citizens to choose between "high benefits, high taxes" and "low benefits, low taxes," responses split right down the middle ( 37 percent vs. 39 percent). Surprisingly, men turned out to be more supportive of the high benefit/high tax model (43 percent of men vs. 32 percent of women), perhaps because women were responsible for budgeting in most Japanese households and were concerned about long-rumored increases in the consumption tax (Asahi Shinbun, July 26, 2008).

Despite this popular split on the proper role of government, the immediate message for Japanese politicians was clear. The public wanted to keep its social benefits, but raising taxes was dangerous, as proved by the repeated electoral losses the LDP suffered after proposing introduction of a consumption tax in 1978, actually introducing a tax of 3 percent in 1989 , and then raising the rate to 5 percent in 1997. If politicians and parties were to strike a balance of responsibility and appeal, they needed to prove that they had cut "unnecessary" spending-overwhelmingly particularistic spending - before voters would allow them to raise taxes or cut pensions and health care.

\section{Electoral Reform and Revision of Political Campaigning Laws}

Calls for electoral reform grew more intense in the early 1990s in response to political scandals and a perceived lack of political leadership. Even though most politicians were reluctant to change the rules under which they had won office, no party wanted to appear to oppose reform (Reed and Thies 2001). Electoral reform in 1994 replaced the House of Representatives' SNTV/medium-sized constituency system with a mixture of single-member districts ( 300 seats) and proportional representation (since the 2000 election, 180 seats in eleven regional blocs). The end of SNTV greatly decreased intraparty competition and reliance on delivery of pork barrel spending as a way for candidates to differentiate themselves. Party leaders gained more effective control over nominations. The role of factions declined, while party labels, ideology, and programmatic intentions grew more important, symbolized by the increasingly large role played by party manifestos. Reforms to the campaign financing system, including public funding of elections, further 
strengthened the party leadership and weakened factions (Rosenbluth and Thies 2010). Prime ministers began to develop significant electoral coattails (Kabashima 2004). Backbench members of the LDP had long viewed their party leaders as a greater threat to their electoral prospects than the opposition parties, but they reluctantly came to see Prime Minister Koizumi and his successors as necessary allies.

As predicted by Duverger's Law, an electoral system dominated by single-member districts encouraged the emergence of a two-bloc, if not quite a two-party, system. The LDP paid more attention to median voters. The DPJ, once far behind the LDP in public support and virtually nonexistent in many parts of the country, gradually drew even with the LDP and won a plurality of seats in the 2007 election to the House of Councillors before winning a decisive victory in the House of Representatives election in 2009. The DPJ, like the LDP, remained ideologically diverse and politically opportunistic, promising more services with fewer taxes, but on balance it clearly leaned away from particularistic spending on roads, bridges, and agricultural improvements and toward greater spending on social welfare.

\section{Administrative Reforms}

If electoral reform weakened factionalism and provided an incentive to decrease the role of particularistic spending, administrative reforms, particularly the major governmental reorganization promoted by Prime Minister Hashimoto (1996-1998) and implemented since 2001, provided strengthened capabilities to restrict particularism in favor of programmatic spending. The Hashimoto reforms represented a long-term project to strengthen Japanese political leadership, a response to complaints of government weakness after the Kobe earthquake and sarin gas attacks on the Tokyo subway, and a short-term reaction to increased competition from Shinshintō, one of the predecessors of the DPJ. The reforms slimmed down the central bureaucracies, strengthened the legal position of the prime minister and cabinet (Shinoda 2005), and created within the cabinet a Council on Economic and Fiscal Policy (CEFP) of around ten members, chaired by the prime minister and led by one of his closest lieutenants, to oversee economic policymaking without being restricted by the interests and perspectives of any one ministry and its constituents. From its initiation, the four private members - two business executives and two economists-took the initiative to pare particularistic spending (Shimizu 2007). 
Prime Minister Koizumi also passed two important policies that changed the balance of power between central and local governments, thus weakening the clientelistic logic sketched by Scheiner (2005): "trinity reforms" redirected a portion of central government revenues to the localities, while renewed efforts at rationalization led to the consolidation of many local governments. For decades, local communities and politicians had resisted the recurrent attempts of the Ministry of Finance to reduce the number of local governments, but under Koizumi, major progress occurred: at the end of fiscal year 2003 Japan had 3,212 cities, towns, and villages; three years later, only 1,821 were left, a decrease of more than 43 percent. ${ }^{37}$ Many local politicians lost their jobs and their ability to support backbench MPs in the Diet. In the 2007 House of Councillors election, newly merged cities witnessed declines in turnout and support for the LDP (Horiuchi and Saito 2009).

Prime Minister Koizumi and his chief economic adviser, Heizo Takenaka, aggressively used the new policy machinery to shrink particularism. They reduced public works every year, forced banks to write off bad loans to politically connected zombie companies, merged and shrank public financial institutions, and privatized the post office. Koizumi's successors were politically weak and short-lived, and the sense of urgency declined as the economy recovered after 2003. Reform fatigue set in, as some of the less attractive aspects of spending cuts and deregulation came to the fore. Yet if Koizumi's successors attempted fewer new policy initiatives, constriction of particularistic spending under both the General Account Budget and the Fiscal Investment and Loan Program continued apace even after Koizumi and Takenaka left the stage. The CEFP, if more muted than under Takenaka and more constrained by LDP politics, continued in a largely neoliberal direction. The major battles within the LDP pitted neoliberals, who emphasized expenditure cuts, against fiscal conservatives who wanted to balance spending cuts with tax increases, while advocates of particularistic spending made few inroads (Asahi Shinbun, September 27, October 23, 2007).

\section{Conclusion}

Despite the storied role of particularistic spending in Japanese politics, and strident denunciations by the DPJ, in the last decade or so of LDP rule, the role of particularistic expenditures on roads, bridges, rural airports, agricultural land reclamation, and the like declined sharply. 
Prime Minister Koizumi played a key role in cementing structural reforms and carrying out five years of budget cuts, but many of the trends predated Koizumi, who built on institutional innovations sponsored by Prime Minister Hashimoto in the 1990s. Moreover, restraint on particularistic spending continued under Koizumi's weaker and less charismatic successors. Spending on civil service salaries and amakudari positions, often seen as particularistic in the Japanese context, also declined. The particularistic logic of "concentrated benefits and diffuse costs" looked unassailable when aggregate costs were limited and resources were readily available, but when times grew tough and aggregate spending came in for scrutiny, the task of organizing opponents grew easier, and the lack of an integrating ideological justification rendered pork barrel spending surprisingly vulnerable.

Programmatic spending, in contrast, increased across a wide range of areas, from public order and social welfare to research and development. The two major exceptions were externally oriented programs enjoying only lukewarm support from the public. Spending on defense stagnated and "economic cooperation" assistance declined sharply from its peak in the late 1990s. The exception that proved the rule was education, where spending declined but far less than the decrease in students.

Until recently, even though many Japanese voters felt disappointed by the particularism of the LDP, they were reluctant to commit themselves to the opposition. The DPJ, as a motley coalition cobbled together from small and unstable predecessors, found it difficult to deliver compelling candidates, a clear and consistent platform, and demonstrations of policymaking ability (Miura et al. 2005). By the 2009 election, however, the Tōdai-Asahi survey showed DPJ candidates clearly differentiating themselves from their LDP rivals (Asahi Shinbun, August 19, 31, 2009). Even after the victory glow faded from the new DPJ administration, the public trusted it as much as the LDP to conduct policymaking effectively (Yomiuri Shinbun, January 22, 2010). No longer can Japan's ruling party take a superior reputation for policymaking competence for granted and then indulge in unlimited particularism. In the new competition of "valence" or performance politics (Schofield and Sened 2006; Clarke et al. 2009), parties will have to show that they can deliver the goods to wide swathes of the electorate.

A preliminary canvasing of causes for the swing away from particularism suggests that economic conditions and the external security environment played only limited roles in the shift away from particularism (see Table 2). The end of the Cold War made partisan turnover 
Table 2 Forces Constricting Particularism in Japan

\begin{tabular}{|c|c|c|}
\hline Factor & Mechanisms & Impact \\
\hline $\begin{array}{l}\text { International } \\
\text { environment }^{\mathrm{a}}\end{array}$ & $\begin{array}{l}\text { Security environment } \\
\text { - End of Cold War; greater (but } \\
\text { not complete) acceptability } \\
\text { of center-left parties } \\
\text { International political economy } \\
\text { - "Japan premium" paid by } \\
\text { Japanese banks; greater } \\
\text { concern for soundness of } \\
\text { Japanese financial system } \\
\text { - Increasing share of stock } \\
\text { ownership and trading by } \\
\text { foreign investors; greater } \\
\text { sensitivity to complaints of } \\
\text { irresponsible spending } \\
\text { - Declining household savings; } \\
\text { future need to sell Japanese } \\
\text { government bonds to foreigners }\end{array}$ & $\begin{array}{l}\text { - Increasing recognition of need } \\
\text { to restrain spending, but little } \\
\text { immediate impact }\end{array}$ \\
\hline $\begin{array}{l}\text { Domestic } \\
\text { economic } \\
\text { factors }^{\mathrm{a}}\end{array}$ & $\begin{array}{l}\text { - Weak tax revenues } \\
\text { - Upturn in debt servicing costs } \\
\text { - Shrinking of "permanent } \\
\text { employment" system }\end{array}$ & $\begin{array}{l}\text { - Constraint on spending } \\
\text { - Pressure for safety-net } \\
\text { expenditures and tax } \\
\text { increases to finance them }\end{array}$ \\
\hline $\begin{array}{l}\text { Demographic } \\
\text { change }\end{array}$ & $\begin{array}{l}\text { - Increasing elderly population, } \\
\text { declining birthrate and } \\
\text { working-age population } \\
\text { - Aging farmers, shrinking } \\
\text { rural communities }\end{array}$ & $\begin{array}{l}\text { - Increased demand for } \\
\text { particularistic and especially } \\
\text { programmatic spending } \\
\text { - Urban backlash against } \\
\text { particularistic spending }\end{array}$ \\
\hline $\begin{array}{l}\text { Partisan } \\
\text { affiliation, } \\
\text { media and } \\
\text { public opinion }\end{array}$ & $\begin{array}{l}\text { - Surge of floating voters; } \\
\text { politicians less able to rely } \\
\text { on particularistically oriented } \\
\text { organized voters } \\
\text { - More varied and lively political } \\
\text { news media; more challenges } \\
\text { to policy status quo }\end{array}$ & $\begin{array}{l}\text { - Shift in demand from } \\
\text { particularistic to } \\
\text { programmatic spending (but } \\
\text { causality complex) }\end{array}$ \\
\hline $\begin{array}{l}\text { Revisions to } \\
\text { electoral } \\
\text { and campaign } \\
\text { financing } \\
\text { systems }\end{array}$ & $\begin{array}{l}\text { - SNTV replaced by single- } \\
\text { member districts/PR in } \\
\text { House of Representatives } \\
\text { - Public financing of elections, } \\
\text { greater regulation of } \\
\text { political financing }\end{array}$ & $\begin{array}{l}\text { - Party heads stronger; factions, } \\
\text { backbenchers weaker; fewer } \\
\text { incentives to deliver pork } \\
\text { - Programmatic orientation } \\
\text { stronger }\end{array}$ \\
\hline $\begin{array}{l}\text { Administrative } \\
\text { reforms }\end{array}$ & $\begin{array}{l}\text { - Stronger PM and cabinet; } \\
\text { streamlined bureaucracy; } \\
\text { consolidation of local } \\
\text { governments }\end{array}$ & $\begin{array}{l}\text { - Greater capacity to control } \\
\text { spending }\end{array}$ \\
\hline
\end{tabular}

Note: a. International environment and domestic economic factors are less significant than other factors. 
more conceivable, while the increase in direct, and especially portfolio, investment in Japan made policymakers more sensitive to the concerns of foreign investors, who tended to frown on particularism. The concerns probably were not pressing enough, however, to account for the changes in the last years of LDP rule. Similarly, the weakness of the domestic economy, though worrisome, particularly after the bankruptcies of major financial firms in 1997, probably did not exert a major influence: low inflation eased the burden of servicing public debt, and programmatic spending, while arguably more fair and economically more useful than particularistic outlays, typically cost more.

In contrast, demographic change exerted direct and intense pressure for greater programmatic spending, particularly on pensions and health insurance. Similarly, the growth of unaffiliated floating voters in the 1990s threatened the LDP's traditional strategy of providing particularistic goodies to well-organized voting groups such as farmers or doctors.

Another powerful force against particularism was reform of the electoral and campaign finance systems, which reduced intraparty competition, strengthened the control of party leaders over nominations and ideology, and gave parties an incentive to focus on median voters rather than relying on a conglomeration of interest groups and electoral niches. Electoral reform and heightened concern for median voters help account for some important policy changes not easily explicable in terms of demographic shifts, such as the initiation of elder care, the increase in subsidies for national pensions, and continued increases in spending on public order even after the collapse of the supposed crime wave.

Electoral reform, however, is difficult to disentangle from demographic and partisan shifts. Adoption of the new mixed electoral system itself reflected a number of other factors, including recurrent scandals, dissatisfaction with existing parties, and the decline of traditional organized voting groups relative to floating voters, as well as the end of the Cold War and the bursting of the economic bubble. Even if Japanese politicians had not modified the electoral system, changes in demography, news media, and partisanship would have remained powerful, and the financial pressures to cut all but essential spending would have continued to grow. Moreover, while Japan's mixed electoral system clearly creates less intraparty competition than occurred under the old SNTV system, it is dominated by single-member districts, which tend to produce more particularistic outcomes than is true of the proportional representation systems common in continental Europe (Persson and 
Tabellini 2003). Factions may have declined sharply, but change in the campaign styles of individual Diet members was limited, and the LDP remained unchallenged at the local and prefectural levels (Martin and Steel 2008). Pressure from the opposition fluctuated, and as late as the aftermath of the 2005 election, the opposition seemed weaker than ever. Only victory in the Upper House election of 2007 enabled the DPJ to present itself as a peer challenger to the LDP and pave the way to capturing the Lower House. Similarly, administrative reforms strengthening the position of the prime minister and cabinet simultaneously reflected the new pressures created by electoral revision, responded to long-term criticisms about venality and lack of leadership in Japanese politics, and made it easier to implement changes appealing to the median voter. Reforming the electoral system in Japan undoubtedly exerted an impact on policy outcomes, but the delineation of exact contours and intersection with other factors, including administrative reforms, awaits further research.

Particularism will not die out completely, of course. Individual politicians always look for chances to claim credit for bringing specific benefits to their constituencies. Moreover, change in partisan rule in 2009 inevitably implied redirecting some political largesse from LDP supporters to groups sympathetic to the DPJ. The DPJ made some particularistic appeals in its winning campaign and upon assuming office immediately froze the privatization of the post office.

Overall, though, the DPJ further cut public works such as agricultural land improvement districts (down nearly two-thirds from the already reduced level under the LDP; Asahi Shinbun, February 1, 2010) and favored greater provision of programmatic goods such as support for families of school-age children. With higher unemployment and an aging society, pressure to strengthen the social safety net will only grow. Given the grim economic and financial situation facing Japan, the real challenge will be raising taxes to pay for these and other programmatic goods - and to service the towering national debt.

Programs and ideology have come to the fore in Japan, as they have elsewhere (Poole and Rosenthal 1997). Particularistic spending will become important primarily not as hefty hunks of pork but as political bacon bits-modest side payments to make it easier for legislators to support programmatic spending or tax increases (cf. Ellwood and Patashnik 1993). Future research on Japanese politics will need to expand beyond studies of interest group politics and particularistic money games to capture the interplay between individual politicians 
seeking reelection in local districts and party leaders seeking to fashion and coordinate policy platforms.

Gregory W. Noble is professor of politics and public administration at the University of Tokyo's Institute of Social Science. His publications include "Japanese and American Perspectives on Regionalism in East Asia," in International Relations of the Asia-Pacific, and "Japanese Political Leadership and Structural Reform," in Beyond the 'Lost Decade': The Koizumi Reforms (in Japanese).

\section{Notes}

1. Ministry of Finance (hereafter, MOF), "Nihon no zaisei o kangaeru, heisei 20 nen 9 gatsu" (Considering Japan's finances, September 2008), at www.mof.go.jp/jouhou/syukei/sy014/sy014s.htm; all sites accessed January 22,2010

2. MOF, "Dai 5 hyō, Meiji 26 nendo ikō ippan kaikei saishutsu shokan betsu yosan" (Table 5, general account expenditure budget by ministry or agency from 1894 on), at www.mof.go.jp/jouhou/syukei/zaiseitoukei/05.xls.

3. OECD Economic Outlook No. 86, November 2009, Annex Table 25, "General Government Total Outlays," at www.oecd.org/dataoecd/5/51/ 2483816.xls.

4. CESifo Dice Report, "Social Expenditures in OECD Countries," January 2006, pp. 53-54, at www.ifo.de/pls/guestci/download/CESifo\%20DICE \%20Report\%202006/CESifo\%20DICE\%20Report\%201/2006/dice report106-db2.pdf.

5. MOF, "Ippan kaikei saishutsutō no suii [tōsho beesu]" (The trend of general account expenditures, etc. [initial budget basis]), at www.mof.go.jp/ jouhou/syukei/siryou/sy1703d.pdf.

6. OECD Economic Outlook No. 86, November 2009, Annex Table 25, "General Government Total Outlays," at www.oecd.org/dataoecd/5/51/ 2483816.xls.

7. OECD Economic Outlook No. 86, November 2009, Annex Table 27, "General Government Financial Balances," at www.oecd.org/dataoecd/5/51/ 2483816.xls.

8. MOF, "Heisei 20 nendo hosei yosan (dai ni gō) ni tsuite" (On the second supplementary budget for fiscal year 2008), at www.mof.go.jp/jouhou/ syukei/h20/hosei201220a.pdf.

9. MOF, "Heisei 2009 nendo yosan no setsumei" (Explanation of the budget for fiscal year 2009), at www.mof.go.jp/seifuan21/setumei/h21y_b.pdf, p. 5.

10. MOF, "Keizai kiki taisaku kankeihi no gaiyō" (An overview of expenditures related to measures taken to counter the economic crisis), 2009, at www.mof.go.jp/jouhou/syukei/h21/sy210427/hosei210427c.pdf. 
11. MOF, "Heisei 21 nendo yosan no henseitō ni kansuru kengi" (Recommendations on the compilation, etc., of the budget for fiscal year 2009), November 26, 2008, at www.mof.go.jp/singikai/zaiseseido/tosin/zaiseia201126/ zaiseia201126_00.pdf, II-3-1.

12. MLIT (Ministry of Land, Infrastructure, Transport and Tourism), "Kensetsu kōji juchū dōtai tōkei chōsa [ōtei 50 sha]" (Dynamic statistical survey of orders for construction work [50 large firms]), at www.stat.go.jp/data/ getujidb/zuhyou/m01.xls.

13. MOF, "Heisei 21 nendo yosan no setsumei" (Explanation of the budget for fiscal year 2009), at www.mof.go.jp/seifuan21/setumei/h21y_b.pdf, 5.

14. MAFF (Ministry of Agriculture, Forestry and Fisheries), "Heisei 14 nendo kessan no gaiyō" (An overview of the audited budget for fiscal year 2002) at www.maff.go.jp/j/budget/2002/kessan.html; MAFF, "Heisei 19 nendo nōrinsuisanshō no kessan no gaiyō" (An overview of MAFF's audited budget for fiscal year 2007), at www.maff.go.jp/j/budget/pdf/19ketu.pdf.

15. Cabinet Office, "Fushō-betsu tōkei tantō shokuinsu no suii (Shōwa 35Heisei 19 nendo)" (Trends in the number of statistical personnel by Ministry and Agency [1960-2007]), at www5.cao.go.jp/statistics/wg/wg1/wg1_6/ siryou_2.pdf: 3 .

16. MIC (Ministry of Internal Affairs and Communications), Administrative Management Bureau, "Kuni no gyōsei kikan no teiin kanri oyobi genryō/ kōritsu-ka no torikumi ni tsuite-gyōsei genryō/kōritsu-ka yūshikisha kaigi (daiikkai) setsumei shiryō" (On measures to manage the number of budgetauthorized personnel in national administrative agencies and reduce their numbers and increase their efficiency-explanatory materials for the first meeting of the conference of experts on decreasing numbers and increasing efficiency), January 31, 2006, at www.gyoukaku.go.jp/genryoukourituka/dail/siryou5.pdf.

17. MOF, "Heisei 21 nendo yosan no henseitō ni kansuru kengi" (Recommendations on the compilation, etc., of the budget for fiscal year 2009), November 26, 2008, at www.mof.go.jp/singikai/zaiseseido/tosin/zaiseia201126/ zaiseia201126_00.pdf, II-2-10 (p. 98).

18. Kokka kōmuin seido kaikaku kihonhō (Heisei 20 nen rokugatsu 13 nichi hōritsu dai 68 gō) (Basic law on the reform of the national civil service system [Law 68, June 13, 2008]), at http://law.e-gov.go.jp/announce/ H20HO068.html.

19. MOF, "Ippan kaikei saishutsutō no suii (tōsho beesu)" (Trends in general account expenditures [initial basis]), at www.mof.go.jp/jouhou/ syukei/siryou/sy1608d.pdf; MOF, "Ippan kaikei saishutsutō no suii (tōsho beesu)" (Trends in general account expenditures [initial basis]), at www .mof.go.jp/jouhou/syukei/siryou/sy2010d.pdf.

20. MOF, Shukeikyoku, "Kaku keihi no pointo (21 nendo seifu an)" (The point of each expenditure [fiscal year 2009 government draft]), December 2008, at www.mof.go.jp/seifuan21/yosan009.pdf: 1.

21. MEXT (Ministry of Education, Culture, Sports, Science and Technology), "Zaigakusha sū (Nenjibetsu)" (Students [National, Local and Private], 1948-2007), at www.mext.go.jp/b_menu/toukei/002/002b/20/009.xls; MEXT, 
"Kyōin sū (Nenjibetsu)" (Teachers [National, Local and Private], 1948-2007), at www.mext.go.jp/b_menu/toukei/002/002b/20/010.xls.

22. MOF, Budget Bureau, "Kaku keihi no pointo (21 nendo seifu an)" (The point of each expenditure [fiscal year 2009 government draft]), December 2008, at www.mof.go.jp/seifuan21/yosan009.pdf: 6 .

23. MOF, "Current Japanese Fiscal Conditions and Issues to Be Considered,” 2008, at www.mof.go.jp/english/budget/pamphlet/cjfc2008.pdf: 44.

24. MEXT, "Kaigai oyobi wagakuni no kenkyū katsudō no gaiyō. i. kenkyū hi" (An overview of research activities abroad and in Japan. i. Research expenditures), at www.mext.go.jp/b_menu/toukei/006/006b/080728/001.pdf, 10 .

25. Supreme Court data collated in Winet (Women's Information Network), "Seibetsu saibankan sū oyobi josei hiritsu no suii (1977, 1985-2009)" (The sex of judges and trends in the share of females [1977, 1985-2009]), at winet.nwec.jp/toukei/save/xls/L118090.xls.

26. MOF, "Heisei 2009 nendo yosan no setsumei" (Explanation of the budget for fiscal year 2009), at www.mof.go.jp/seifuan21/setumei/h21y_b.pdf: 8 .

27. Public Relations Office, Government of Japan (Naikakufu daijin kanbō seifu kōhōshitsu), "Shakai ishiki ni kansuru yoron chōsa" (Public opinion survey on social consciousness), at www8.cao.go.jp/survey/h17/h17-shakai/images/ z16.gif; www8.cao.go.jp/survey/h20/h20-shakai/images/z31.gif.

28. MOF, "Ippan kaikei saishutsutō no suii (tōsho beesu)" (Trends in general account expenditures [initial basis]), at www.mof.go.jp/jouhou/syukei/ siryou/sy2108d.pdf.

29. Department of National Accounts, ESRI (Economic and Social Research Institute), Cabinet Office, "Heisei 19 nendo kokumin keizai keisan kakuhō (furō-hen), pointo" (2007 SNA confirmed data [flow], main points), at www.esri.cao.go.jp/jp/sna/h19-kaku/081225/point.pdf.

30. Cabinet Office, National Accounts for 2008 (gross domestic product in real terms), at www.esri.cao.go.jp/en/sna/h20-kaku/20fcm1rn_en.xls.

31. MOF, "Highlights of the Budget for FY2009," at www.mof.go.jp/ english/budget/e20081224a.pdf: 17.

32. OECD Economic Outlook No. 86, November 2009, Annex Table 32, "General Government Gross Financial Liabilities"; and Annex Table 33, "General Government Net Financial Liabilities," at www.oecd.org/dataoecd/5/51/ 2483816.xls.

33. MOF, "Highlights of the Budget for FY2009," at www.mof.go.jp/ english/budget/e20081224a.pdf: 1722 .

34. National Institute of Population and Social Security Research, Department of Population Structure Research, "Nihon no todōfuken-betsu shōrai suikei jinkō (Heisei 19 nen 5 gatsu suikei)—Heisei 17 (2005)-47 (2035) nen" (Estimated population of Japan by prefecture [May 2007 estimate]: 20052035), at www.ipss.go.jp/pp-fuken/j/fuken2007/gaiyo.pdf: 19.

35. MAFF, Tohoku Regional Agricultural Administration Office, “Tōhoku nōgyō no sugata 2007" (The shape of agriculture in northeast Japan, 2007), at www.maff.go.jp/tohoku/press/sugata2007/pdf/2007-18.pdf. 
36. Cabinet Office, "Kokumin seikatsu ni kansuru yoron chōsa" (Public opinion survey on the life of the people), "seifu ni taisuru yōbō ni tsuite" (demands toward the government), at www8.cao.go.jp/survey/index-ko.html, various years.

37. MIC, "Shichōsonsū no suiihyō (saishinban)" (Table of trends in the number of cities, towns, and villages) [latest edition], January 12, 2010, at www .soumu.go.jp/gapei/pdf/090624_02.pdf.

\section{References}

Calder, Kent. 1988. Crisis and Compensation: Public Policy and Political Stability in Japan, 1949-1986. Princeton: Princeton University Press.

Campbell, John Creighton. 1992. How Policies Change. Princeton: Princeton University Press.

Carey, John M., and Matthew Soberg Shugart. 1995. "Incentives to Cultivate a Personal Vote: A Rank Ordering of Electoral Formulas.” Electoral Studies 14, 4: 417-439.

Clarke, Harold D., David Sanders, Marianne C. Stewart, and Paul F. Whiteley, eds. 2009. Performance Politics and the British Voter. Cambridge: Cambridge University Press.

Curtis, Gerald L. 1988. The Japanese Way of Politics. New York: Columbia University Press.

Democratic Party of Japan. 2009. "2009 Change of Government-The Democratic Party of Japan's Platform for Government: Putting People's Lives First." Tokyo: Democratic Party of Japan.

Eda, Kenji. 2004. Koizumi Seiji no Shōtai: Ma no Kaikakusha ka, Kidai no Petenshi $\mathrm{ka}$ (The true character of Koizumi politics: Genuine reformer or singular confidence man). Tokyo: PHP.

Ellwood, John W., and Eric W. Patashnik. 1993. "In Praise of Pork." The Public Interest 110: 19-33.

Estévez-Abe, Margarita. 2008. Welfare and Capitalism in Postwar Japan. Cambridge: Cambridge University Press.

Hamai, Koichi, and Thomas Ellis. 2007. "Crime and Criminal Justice in Modern Japan: From Re-integrative Shaming to Popular Punitivism.” International Journal of the Sociology of Law 34: 157-178.

Hirose, Michisada. 1989. Seiji to Kane (Politics and money). Tokyo: Iwanami. Hiwatari, Nobuhiro, and Mari Miura, eds. 2002. Ryūdōki no Nihon seiji: 'Ushinawareta 10 nen' no Seijigaku teki Kenshō (Japanese politics in a period of fluidity: A political science analysis of the 'lost decade'). Tokyo: University of Tokyo Press.

Horiuchi, Yusaku, and Jun Saito. 2009. "Removing Boundaries to Lose Connections: Electoral Consequences of Local Government Reform in Japan." Paper presented at the annual meeting of the Midwest Political Science Association 67th Annual National Conference, Chicago, April 2. 
Ihori, Toshihiro. 2008. 'Saishutsu no Muda' no Kenkyū (Research on 'wasteful expenditures'). Tokyo: Nihon Keizai.

Ikeda, Atsuhiko. 2008. Zusetsu Nihon no Zaisei, Heisei 20 Nenban (Japan's public finances illustrated, 2008). Tokyo: Tōyō Keizai Shinpōsha.

Inoguchi Takashi and Iwai Tomoaki. 1987. 'Zoku Giin' no Kenkyū: Jimintō Seiken o Gyüjiru Shuyakutachi (Research on 'policy tribes': The leading actors who control the LDP government). Tokyo: Nihon Keizai Shinbunsha.

Institute of Social Science, University of Tokyo, ed. 2006. Ushinawareta 10 Nen o Koete (2): Koizumi Kaikaku e no Jidai (Beyond the lost decade (2): Toward the Koizumi reforms). Tokyo: University of Tokyo Press.

Johnson, Chalmers. 1986. "Tanaka Kakuei, Structural Corruption, and the Advent of Machine Politics in Japan." Journal of Japanese Studies 12, 1: $1-28$.

Kabashima, Ikuo. 2004. Sengo Seiji no Kiseki: Jimintō Shisutemu no Keisei to Hen'yo (The trajectory of postwar politics: The formation and transformation of the LDP system). Tokyo: Iwanami.

Kamemoto, Kazuhiko. 2005. Kōkyō Jigyō no Sakugen to sono Eikyō (Reduction in public work and its impact), National Diet Library. Refurensu 1: 9-28.

Koh, B. C. 1989. Japan's Administrative Elite. Berkeley: University of California Press.

Krauss, Ellis S. 2000. Broadcasting Politics in Japan: NHK and Television News. Ithaca: Cornell University Press.

Maclachlan, Patricia L. 2004. "Post Office Politics in Modern Japan: The Postmasters, Iron Triangles, and the Limits of Reform." Journal of Japanese Studies 30, 2: 281-313.

Martin, Sherry L., and Gill Steel, eds. 2008. Democratic Reform in Japan: Assessing the Impact. Boulder: Lynne Rienner.

MEXT (Ministry of Education, Culture, Sports, Science and Technology). 2008. Kagaku Gijutsu Hakusho (White paper on science and technology).

Ministry of Justice. Annual. Hōmu Nenkan (Yearbook of legal affairs).

Miura, Mari, Kap Yun Lee, and Robert Weiner. 2005. "Who are the DPJ? Policy Positioning and Recruitment Strategy.” Asian Perspective 29, 1: 49-77.

Nakano, Masashi. 2009. Amakudari no Kenkyū: Sono Jittai to Mekanizumu no Kaimei (Research on amakudari: An explanation of the real situation and the mechanism that causes it). Tokyo: Akashi Shoten.

Nakata, Kazuyoshi. 2009. "Nihon no kakei chochiku-ritsu no chōkitekina dōkō to kongo no tenbō" (The long-term trend and outlook of Japan's household savings rate). Kikan seisaku keiei kenkyū [Mitsubishi UFJ Bank]1, 113-128.

National Police Agency (Keisatsuchō). Annual. Hanzai Hakusho (White paper on crime).

Nihon Keizai Shinbunsha. 1983. Jimintō Seichōkai (The LDP's Policy Affairs Research Council). Tokyo: Nihon Keizai Shinbunsha.

Noble, Gregory W. 1998. Collective Action in East Asia: How Ruling Parties Shape Industrial Policy. Ithaca: Cornell University Press. 
2005. "Front Door, Back Door: The Reform of Postal Savings and Loans in Japan." The Japanese Economy 33, 1: 107-123.

- 2007. "Stealth Populism: Administrative Reform in Japan." In The Repositioning of Public Governance: Global Experience and Challenges, ed. Gerald E. Caiden and Tsai-Tsu Su. Taipei: Best-Wise.

OECD (Organization for Economic Cooperation and Development). 2000, 2008, 2009. Annual. Education at a Glance: OECD Indicators. Paris: OECD. 2008. OECD in Figures. Paris: OECD.

Ōtake, Hideo. 1999. Nihon Seiji no Tairitsu Jiku-93 Nen ikō no Seikai Saihen no naka de (Axes of cleavage in Japanese politics in the political reorganizations after 1993). Tokyo: Chuo Shinsho.

Persson, Torsten, and Guido Tabellini. 2003. The Economic Effects of Constitutions. Cambridge: MIT Press.

Poole, Keith T., and Howard Rosenthal. 1997. Congress: A Political-Economic History of Roll Call Voting. New York: Oxford University Press.

Reed, Steven R. 1994. "Democracy and the Personal Vote: A Cautionary Tale from Japan." Electoral Studies 13, 1: 17-28.

Reed, Steven R., and Michael F. Thies. 2001. "The Causes of Electoral Reform in Japan.” In Mixed-Member Electoral Systems: The Best of Both Worlds? ed. M. S. Shugart and M. P. Wattenberg. New York: Oxford University Press.

Rosenbluth, Frances McCall, and Michael F. Thies. 2010. Japan Transformed: Political Change and Economic Restructuring. Princeton: Princeton University Press.

Saito, Jun. 2009. "Infrastructure as the Magnet of Power: Explaining Why Japanese Legislators Left and Returned to the LDP." Journal of East Asian Studies 9, 3: 467-493.

Schaede, Ulrike. 2008. Choose and Focus: Japanese Business Strategies for the 21st Century. Ithaca: Cornell University Press.

Scheiner, Ethan. 2005. Democracy Without Competition in Japan: Opposition Failure in a One-Party Dominant State. Cambridge: Cambridge University Press.

Schofield, Norman, and Itai Sened. 2006. Multiparty Democracy: Elections and Legislative Politics. Cambridge: Cambridge University Press.

Shimizu, Masato. 2007. Keizai Zaisei Senki: Kantei Shidō, Koizumi kara Abe $e$ (War chronicle of the Council on Economic and Fiscal Policy: Cabinet leadership from Koizumi to Abe). Tokyo: Nihon Keizai Shinbunsha.

Shinoda, Tomohito. 2005. "Japan's Cabinet Secretariat and Its Emergence as Core Executive." Asian Survey 45, 5: 800-821.

Shōgenji, Shin'ichi. 2008. "Nōgyō ninaite seisaku no kadai" (Issues in policies toward agriculturalists). NIRA (National Institute for Research Advancement), monogurafu shiriizu 24, March.

Tanaka, Aiji, and Sherry Martin. 2003. "The New Independent Voter and Japan's Evolving Party System." Asian Perspective 27, 3: 21-51.

Taniguchi, Masaki, Sugawara Taku, and Kabashima Ikuo. 2005. "Jimin ni suwingu shita yawarakai kōzō kaikakuha" (The soft structural reform group that swung to the LDP). Ronza 126: 93-104. 
Tiberghien, Yves. 2007. Entrepreneurial States: Reforming Corporate Governance in France, Japan, and Korea. Ithaca: Cornell University Press.

Tokyo Stock Exchange Group. 2008. 2008 Shareownership Survey. Tokyo: Tokyo Stock Exchange Group.

- 2009. Fact Book 2009. Tokyo: Tokyo Stock Exchange Group.

Wilson, James Q. 1989. Bureaucracy: What Government Agencies Do and Why They Do It. New York: Basic Books.

Yoshida, Kenzo, Yung-Hsing Guo, and Li-Hsuan Cheng. 2006. "The Japanese Pension Reform of 2004: A New Mode of Legislative Process." Asian Survey 46, 3: 381-400.

Zaidan Hōjin Gyōsei Kanri Sentaa. 2007. Deetabukku Nihon no Gyōsei 2007 (Data book: Public administration in Japan, 2007). Tokyo: Zaidan Hōjin Gyōsei Kanri Sentaa.

- 2008. Deetabukku Nihon no Gyÿsei 2009 (Data book: public administration in Japan). Tokyo: Zaidan Hōjin Gyōsei Kanri Sentaa. 
UNIVERSITY OF

CALIFORNIA PRESS

JOURNALS DIGITAL PUBLISHING

\section{ASIAN \\ SURVEY}

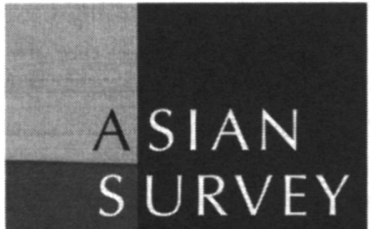

EDITOR//

Lowell Dittmer

DETAILS /

ISSN: 0004-4687

elSSN: $1533-838 \mathrm{X}$

February, April, June, August,

October, December

Impact Factor: 0.341

Asian Survey provides penetrating analysis and commentary on the politics, economics, social issues, and foreign relations of countries from Afghanistan to the Pacific Rim. Since 1961, this scholarly yet accessible journal has offered empirically grounded insider perspectives on important current events, making it one of the most widely read and quoted sources on developments in the region.

WW W. UCPRESSJOURNALS, COM 